\title{
A Surgical View of Photodynamic Therapy in Oncology: A Review
}

\author{
K. Moghissi ${ }^{1} \quad$ Kate Dixon $^{1}$ Sally Gibbins ${ }^{1}$ \\ ${ }^{1}$ The Yorkshire Laser Centre, Goole and District Hospital, Goole, East \\ Yorkshire, United Kingdom \\ Address for correspondence K. Moghissi, BSc, MD, MS (Chir), FRCS \\ (Ed \& Eng), FETCS, The Yorkshire Laser Centre, Goole and District \\ Hospital, Woodland Avenue, Goole DN14 6RX, United Kingdom \\ Surg J 2015;1:e1-e15. \\ (e-mail: kmoghissi@yorkshirelasercentre.org).
}

\begin{abstract}
Keywords

- PDT in oncology

- PDT for surgeons

Clinical photodynamic therapy (PDT) has existed for over 30 years, and its scientific basis has been known and investigated for well over 100 years. The scientific foundation of PDT is solid and its application to cancer treatment for many common neoplastic lesions has been the subject of a huge number of clinical trials and observational studies. Yet its acceptance by many clinicians has suffered from its absence from the undergraduate and/or postgraduate education curricula of surgeons, physicians, and oncologists. Surgeons in a variety of specialties many with years of experience who are familiar with PDT bear witness in many thousands of publications to its safety and efficacy as well as to the unique role that it can play in the treatment of cancer with its targeting precision, its lack of collateral damage to healthy structures surrounding the treated lesions, and its usage within minimal access therapy. PDT is closely related to the fluorescence phenomenon used in photodiagnosis. This review aspires both to inform and to present the clinical aspect of PDT as seen by a surgeon.
\end{abstract}

At the dawn of the 20th century, Oscar Raab studied the effects of acridine on paramecia cultures in Munich's Laboratories of Von Tappeiner, noting that in the dark acridine had no harmful effect on the growth of this protozoan microorganism, but once exposed to the light, it became lethal to paramecium. ${ }^{1}$ A more detailed study of the mechanisms involved indicated the killing process depended on oxygen in addition to light. The process was named Photodynamische Wirkung. ${ }^{2-4}$ This work has been variably translated in English as photodynamic effect, photodynamic phenomenon, and photodynamic reaction (PDR). It was, in fact, a complex cell-killing phenomenon resulting from the interaction of a chemical compound, a photosensitizer (PS), light, and oxygen. The discovery of Photodynamische Wirkung led von Tappeiner and colleagues to set up a clinical experiment in six patients with skin cancer and thus moved from laboratory level of Photodynamische Wirkung to the Photodynamische Therapie, or photodynamic therapy (PDT). In this article, the term photodynamic reaction is used to mean the events that lead to the killing of cells in vitro and within a laboratory

received

July 15, 2015 accepted after revision

August 25, 2015

published online

October 15, 2015 setting resulting from the interaction of the PS with light in the presence of oxygen. In contrast, the term photodynamic therapy is reserved to mean the combination of PS, light, and oxygen in an in vivo clinical environment. There are associated events modulating the PDR and adding to the complexity of the process to achieve the therapeutic objectives of destruction of unwanted diseased tissue such as cancer. PDT is principally a local treatment dependent on the localization of a chemical agent (the drug) in diseased cells, presensitizing them to a specific light wavelength. The extent of injury and cell death is determined by the dimensions of the presensitized tissue and the physical characteristic of the light.

Many early researchers were aware of the fact that the interaction between light and PSs within the cells not only produced PDR but also led to another related process, namely fluorescence emission. It was also clear that in an in vivo situation the relative simplicity of the laboratory trio of PS, light, and oxygen interactions become an "opera" of gigantic magnitude with the involvement of several interrelated phenomena. PDR and fluorescence emission are in reality
Copyright $\odot 2015$ by Thieme Medical Publishers, Inc., 333 Seventh Avenue, New York, NY 10001, USA. Tel: +1(212) 584-4662.
License terms

10.1055/s-0035-1565246. ISSN 2378-5128.

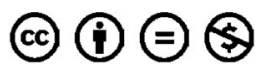


two facets of the same process of light-tissue interaction. The manner in which light interacts with a specific type of tissue is dictated by wavelength-dependent absorption and scattering properties. In the ultraviolet and visible spectrum, tissue optical properties are dominated by endogenous chromophores, which differ in normal and abnormal tissues of the same type. The principal chromophore in human tissues is hemoglobin, which has strong absorption at wavelengths shorter than $600 \mathrm{~nm}$. Other components not only absorb light over specific bands between 250 and $500 \mathrm{~nm}$ but also display characteristic fluorescent emission over the range of 300 to $700 \mathrm{~nm}$. Fluorescent emission is the absorption of an incident light at one wavelength followed by emission of a light at a different (usually higher) wavelength, which ceases almost immediately when the incident radiation stops.

Some tissues exhibit a characteristic fluorescent emission band that is altered when a disease process such as cancer occurs, changing their molecular structures and thus their chromophore components. By using an appropriate wavelength of light, usually within the blue region, one can display the differential fluorescence images, which is the basis of autofluorescence photodiagnosis (PD) (- Fig. 1). ${ }^{5,6}$ Although $\mathrm{PD}$ does not equate to the diagnosis of a specific disease, it is nevertheless an indication of local changes, highlighting the best biopsy location to provide histologic diagnosis. The phenomenon of fluorescence can also be enhanced by using an exogenous fluorophore such as a PS. Such an enhanced PD is useful particularly to surgeons to indicate residual neoplastic infiltration, which may exist at the margin of resection. It may even guide the surgeon in some areas, such as brain surgery, in removal of tumor residue invisible to the naked eye or to microscopic operative devices. ${ }^{7}$

In the first half of the 20th century and until 1978, clinical PDT was performed in a few institutions within an experimental setting, building up the parameters for a given therapy. ${ }^{8,9}$ The initial series of clinical trials was performed by Dougherty and colleagues after synthesis of a porphyrinbased PS hematoporphyrin derivative (HPD). ${ }^{10}$ The trial involved 111 patients with different types of cancers. The immediate results impressively showed that every patient responded to treatment. After this initial success, the problem was to synthesize more PSs, to determine light dose for specific lesions, and to devise methods of illumination of tumors situated within the body rather than on its surface.

The modern era of clinical PDT began in earnest in the early 1980s with the availability of a more refined formulation of HPD, Photofrin. Also, new second-generation drugs and prodrugs were synthetized. ${ }^{11-13}$ Within the next 15 to 20 years, the number of PSs grew, many of which did not leave the laboratory shelves and never ever saw the light of clinical practice. Although efforts continued to synthesize better PSs, there was also development in matching light sources and lasers. ${ }^{14}$

\section{Mechanisms of Photodynamic Therapy}

The groundbreaking work in PDR and PDT by Munich's scientists over a century ago was followed by intense research by many scientists and laboratories throughout the world to unravel the intricacies of the interaction between the three

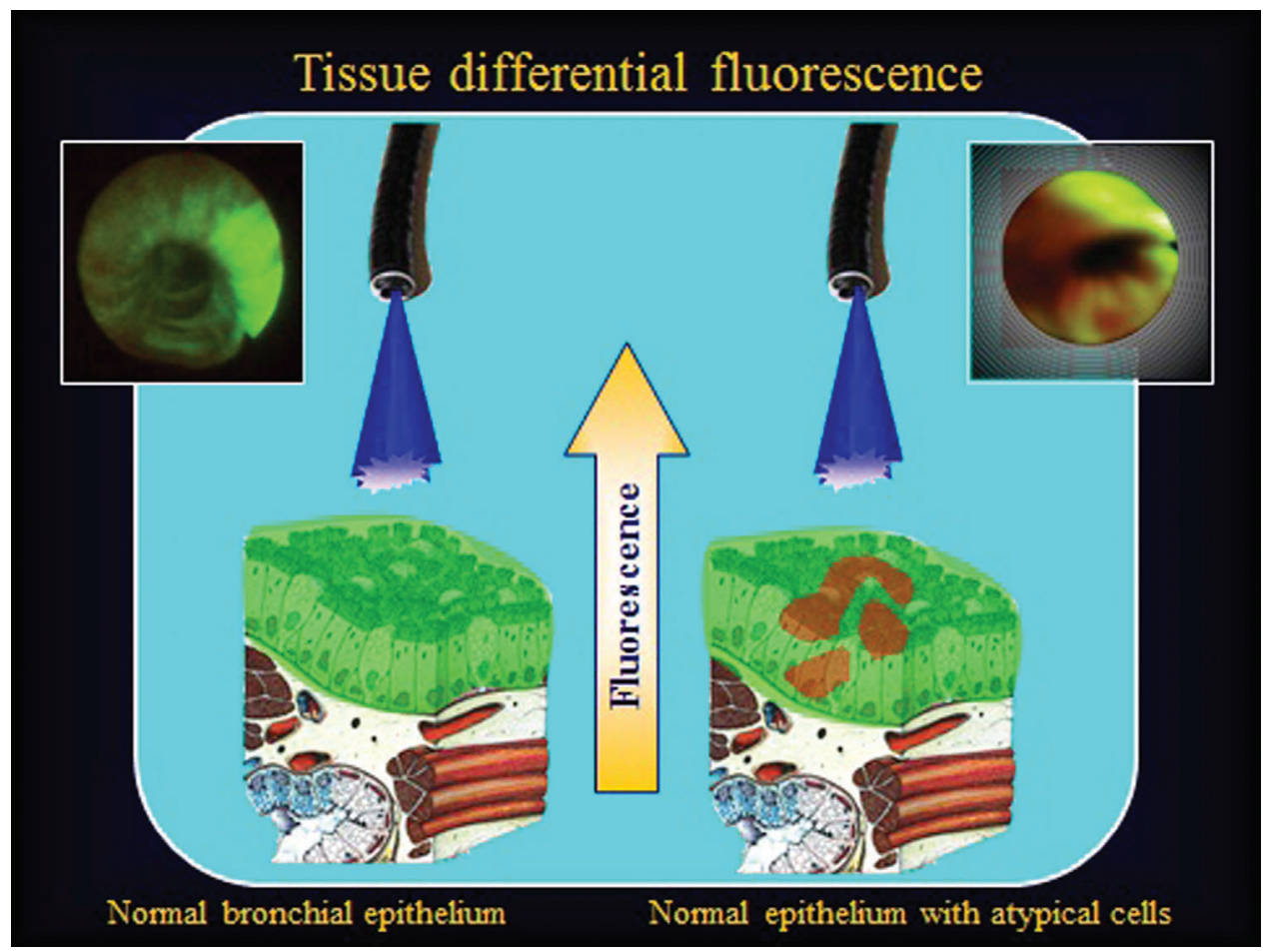

Fig. 1 Diagram and bronchoscopic view of autofluorescence bronchoscopy, using blue light region (440 nm). Normal bronchial mucosa (left). Bronchial mucosa involved by carcinoma in situ (right). 
components of PDT that culminate in the death of the cells under attack. $^{15-17}$

It was clear from the beginnings of PDT that, in complex biological systems such as mammalians and the human body where there are many different cells, tissues, and organs, there is a functional as well as structural interdependence between various groups of tissues that make up different organs. Therefore, PDT though a local phenomenon would affect other parts of the body away from the site of treatment through activation of mechanisms related to general response to injury and via stimulation of the immune system. ${ }^{17,18}$ PDT in a human subject will inevitably involve different sets of phenomena than those in a controlled laboratory environment often concerned with one cell. PDT response in the clinical situation involves several separate and yet related events that can be described under three headings:

1. Direct local injury to the target tissues by the cytotoxic agents released through the PS-light-oxygen interaction, essentially but not entirely related to reactive oxygen species leading to necrosis or accelerated apoptosis

2. PDT damage to vasculature that further enhances necrosis of the targeted lesion by deprivation of oxygen and essential molecules ${ }^{18,19}$

3. PDT stimulation of inflammatory and immune responses that assist the body toward the destruction of unwanted tissues locally as well as altering the immunologic competence more generally ${ }^{16-19}$

\section{Clinical Photodynamic Therapy Components and Devices}

Clinical PDT harnesses the three ingredients of PDR and focuses them to a target area, destroying the cells and tissues that make up a lesion. The three components of clinical PDT are basically those used in a laboratory and experimental setting with several provisos and modifications to suit the human clinical situation: the PS, an appropriate light, and oxygen.

\section{The Photosensitizer}

The PS is a chemical compound that can localize in the abnormal cells, such as cancer. For human usage, a PS has to comply with the requirements of safety and the licensing authorities. - Table 1 shows the family of PSs available for clinical practice, which is not a complete, universally agreed upon, or accepted list of PSs, but comprises those used in many countries.

Provision of chemical structure and characteristics of PSs is not within the scope of this article. These are described in most textbooks on PDT and reviews. ${ }^{20,21}$ Nevertheless, it is relevant to point out that PSs may be classified into two groups: systemic PS and topical PS.

Topical and systemic PDTs and their respective PSs are variations of the same process and their mechanisms follow similar patterns. However, they have different indications and different applications and often use different light

Table 1 Common photosensitizers in use for clinical PDT in oncology (manufacturers and web sites listed in - Appendix 1)

\begin{tabular}{|c|c|c|c|c|}
\hline Family & Name & Alternative/Abbreviation & $\begin{array}{l}\text { Activation } \\
\text { light }(\mathrm{nm})\end{array}$ & Remark \\
\hline Porphyrin & $\begin{array}{l}\text { Hematoporphyrin } \\
\text { derivative }\end{array}$ & $\mathrm{HpD}$ & 630 & Precursor of Photofrin \\
\hline Porphyrin & Photofrin & Porfimer sodium & $630-635$ & Multipurpose \\
\hline Porphyrin (prodrug) & Levulan & 5-ALA & 630 & Topical/skin \\
\hline Porphyrin (prodrug) & Metvix & Methyl-ALA & 630 & Mainly skin \\
\hline Porphyrin (prodrug) & Visudyne & Verteporfin & 619 & Experimental for oncology \\
\hline Porphyrin (prodrug) & $\begin{array}{l}\text { Hexaminolevulinate } \\
\text { hydrochloride }\end{array}$ & HALA & & Fluorescence cystoscopy \\
\hline Texaphyrin & $\begin{array}{l}\text { Lutexaphyrin/lutetium } \\
\text { texaphyrin }\end{array}$ & Lutex, Optrin & 730 & Experimental, clinical \\
\hline Chlorin & Foscan & mTHPC & $525-660^{a}$ & Head and neck, others/variable \\
\hline Chlorin & Talaporfin & & & \\
\hline Chlorin & NPe6 & $\begin{array}{l}\text { Mono-L-aspartyl } \\
\text { chlorin } 6\end{array}$ & 664 & Lung cancer \\
\hline Chlorin & Photochlor & $\mathrm{HPPH}$ & $665-680$ & \\
\hline Bacteriochlorin & TOOKAD & $\begin{array}{l}\text { Metal complex } \\
\text { bacteriochlorin }\end{array}$ & 760 & Vascular targeted, prostate \\
\hline Dye & Photosens & Phthalocyanine & $650-850$ & Various \\
\hline
\end{tabular}

Abbreviations: ALA, aminolevulinic acid; mTHPC, meso-tetraphenyl chlorine; PDT, photodynamic therapy; TOOKAD, Pd-bacteriopheophorbide. a Esophagus. 
sources. Furthermore, the two groups are endowed with their respective advantages and disadvantages.

\section{Systemic Photodynamic Therapy and Photosensitizers} As a general rule, systemic PDT (exemplified by Photofrin PDT, - Table 1) uses intravenous (IV) route of administration of the PSs. These directly enter the circulatory system and reach the target tissue through the bloodstream. Systemic photosensitization by routes other than IV has remained within the domain of experimentation and is not routinely used by PDT clinicians. Systemic photosensitization/PDT ensures wide distribution of the PS, albeit with a higher concentration in neoplastic tissues than normal. It also allows multiple-site illumination, multiple-site PDT, and at-depth illumination, either using an appropriate wavelength of light with deeper penetration or by applying interstitial illumination (light exposure, - Fig. 2). PDT can be performed intraoperatively in conjunction with standard or minimal access surgery.

The main disadvantage is the potential prolonged skin photosensitivity of up to 8 to 10 weeks for some PSs of the porphyrin family, thus potentially adversely affecting the quality of life of the patient.

\section{Topical Photodynamic Therapy}

Topical PDT includes use of the prodrug 5-aminolevulinic acid (ALA) or its variants (see - Table $\mathbf{1}$ ), which, after administration, is converted to protoporphyrin IX, the actual PS. By using ALA PDT topically, the PS protoporphyrin IX is synthesized locally and does not enter into the bloodstream. This ap- proach, however, only reaches tissues within the depth of $\sim 1 \mathrm{~mm}$ from the point of administration. Because topical ALA uptake is so limited, irrespective of the type of light used, photodynamic injury and effects are limited in extent and depth. It also follows that photodynamic skin reaction is limited to the area of treated area.

\section{Appropriate Light}

An appropriate light has a wavelength that matches the characteristics of the PS and is therefore capable of its excitation (activation), which in many instances will have to be a laser capable of generating light of a specific wavelength and emitting variable power to match the requirements of tissues of different optical characteristics. Alternatively, LED may be used for superficial lesions. The currently available PSs used in clinical PDT practice are activated by light within the wavelengths of the visible electromagnetic spectrum, 400 to $700 \mathrm{~nm}$.

- Table 2 shows the wavelength ranges and the corresponding colors from violet to red as well as the light penetration through the skin in function of wavelength and color. The depth of light transmission in a given tissue or organ is an important aspect of the clinical PDT procedure. This aspect is particularly relevant in the case of organs endowed with a rich vasculature, such as an artery, during the course of illumination in PDT, which could lead to an uncontrollable fatal hemorrhage. Determination of light penetration in a given tissue or organ in clinical PDT practice is based on the ex vivo mathematical calculation of parameters involved in optophysics of light-tissue interaction and in vivo

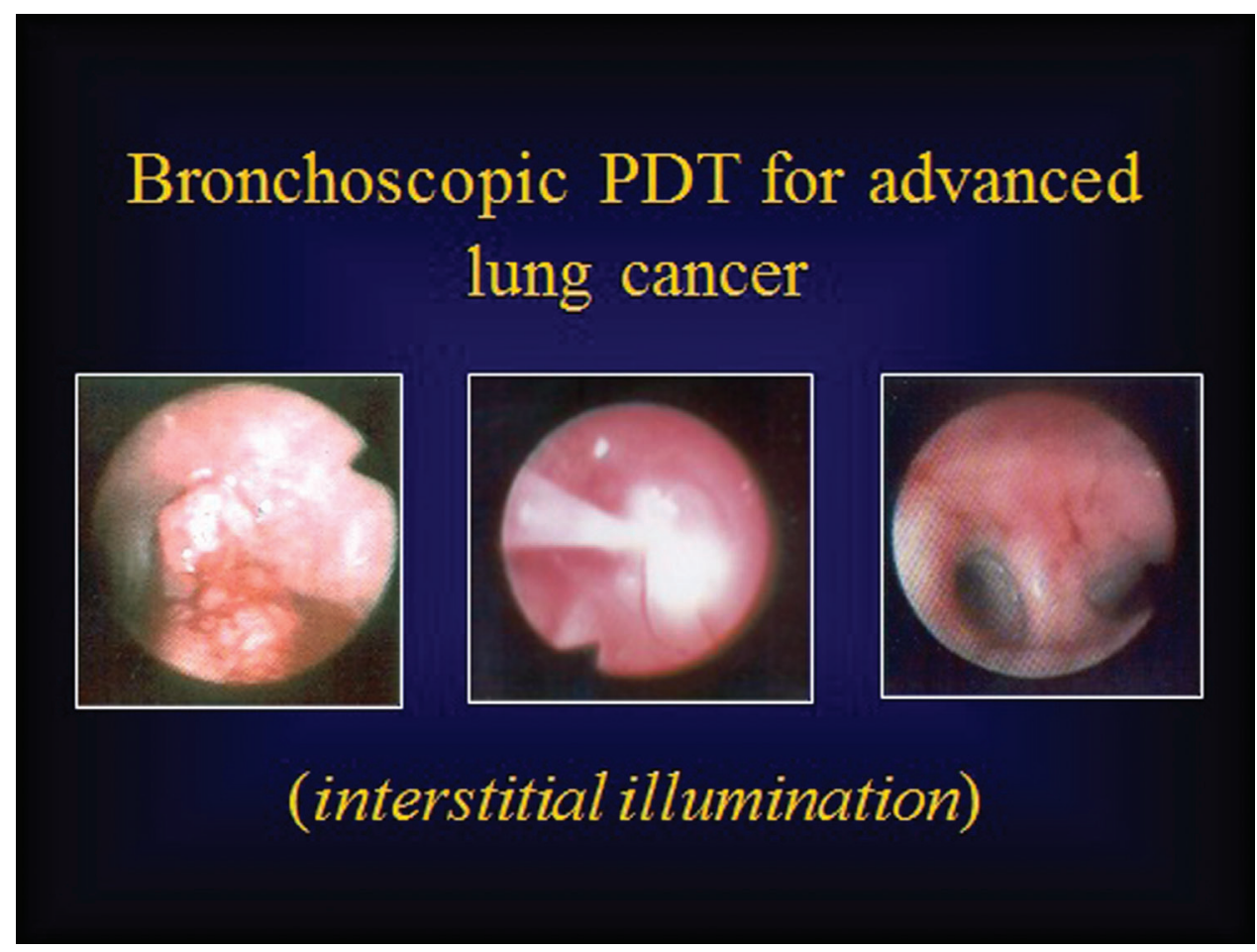

Fig. 2 Bronchoscopic view of a tumor obstructing the opening of left upper lobe bronchus treated by interstitial illumination. Far left: tumor in the left upper lobe bronchus; middle: illumination of the tumor; right: bronchoscopic view of the upper lobe bronchus 6 weeks after photodynamic therapy (PDT) showing complete clearance. 
Table 2 Wavelength of visible lights spectrum and depth of penetration (human skin)

\begin{tabular}{|l|l|l|}
\hline Color & Wavelength $(\mathrm{nm})$ & Penetration depth $(\mathrm{mm})$ \\
\hline Red & $622-780$ & $4-10$ \\
\hline Orange & $597-622$ & $3-4$ \\
\hline Yellow & $577-597$ & 3 \\
\hline Green & $492-577$ & 2 \\
\hline Blue & $455-492$ & 1 \\
\hline Violet & $390-455$ & 1 \\
\hline
\end{tabular}

studies of animals and humans. ${ }^{22,23}$ However, in the final analysis the appropriate measurement in clinical cases and experience of clinicians need to be considered. The general principles that govern the depth or the radius of light transmission in a given organ depend on light factors and tissue factors. As a general rule, the longer the wavelength, the deeper/or wider the light will be transmitted. The higher the power and power density (fluence) settings, the deeper the transmission.

Tissue factors relate to the optical properties of tissues exposed to the light. In humans, the optical properties of an organ result from a mix of heterogeneously structured component tissues, which are a complex summation of ratio of absorption and the scattering of each participating tissue. The relative penetration in skin of different wavelengths of visible light can be seen in - Table 2 . It is nevertheless important to realize that the reported penetration in the skin does not hold true for other tissues or organs whose complex optical properties are not similar to those of the skin. For instance, in the case of bronchial mucosal wall and pulmonary tissues, the red light $(630 \mathrm{~nm})$ penetrates up to $10 \mathrm{~mm}$. In practice, the PDT team should include a clinical physicist or a clinician knowledgeable in optical physics.

From a clinical point of view, the laser device requires a connection for delivery of optical fibers for light emission. The fibers should be of suitable diameter to be accommodated within the delivery channels of endoscopic equipment or surgical instrumentation used in various procedures.

\section{Oxygen}

The third component, oxygen, is available in all living tissues.

\section{Clinical Photodynamic Therapy in Practice}

Clinical PDT is performed as a two-step procedure:

1. Presensitization. The PS is administered systemically (intravenously/orally) or topically. The aim is for the PS to "localize" in the target lesion at a higher concentration than in normal tissue.

2. Illumination. The light is directed to the presensitized tissue/lesion area. In many instances, the light is transmitted via an optical fiber ending in a cylindrical or bulb diffuser, which emits light around its circumference. Al- ternatively, the fiber ends in a microlens, which provides forward emission of light.

Dosimetry of light constitutes an important issue that needs to be mastered by the clinician or clinical (medical) physicist. Between the presensitization and illumination steps, there needs to be a latent period to allow distribution and localization to take place of the PS within the cells/tissues of the lesion.

\section{The Potentials of Photodynamic Therapy in Clinical Practice}

PDT uses minimally invasive techniques and, due to its dependence on PS and matching light, its direct effect is limited to the area of presensitized tissue that is exposed to the appropriate matching light. In this respect, PDT differs from all other local cancer therapy methods because it has a double targeting mechanism. The first is the operator directing the light to the target. The second is the ability of the light with its specific wavelength that matches the absorption characteristics of the PS to "lock" into the presensitized tissues of the target. Therefore, PDT affects the target tissue more precisely with little or no collateral damage to the normal tissue outside the range of the light transmission within illuminated areas. It is repeatable; there is no evidence of development of resistance in target lesions.

PDT can be used within a multidisciplinary setting. It may be incorporated within a combination therapy schedule to be used with or after chemoradiation and surgery. In certain cases, it may be used as a neoadjuvant therapy to downstage the cancer before surgical operation. It may be used in the early stage of several neoplasms with a curative intent. PDT can be used in locally advanced stages of many cancers to achieve palliation of symptoms.

\section{Clinical Indications of Photodynamic Therapy}

For descriptive purposes, the many indications of PDT in clinical practice may be grouped under (1) oncological indications, relating to the destruction of cancer tissues, which is currently the principal indication of PDT, and (2) nononcological indications.

\section{Photodynamic Therapy in Oncology: A Classification}

There are over 5,000 publications concerned with PDT in patients with cancers in different sites. A clinician in a given specialty who considers using PDT for a patient with cancer needs a benchmark that indicates the effectiveness as well as the appropriateness of the treatment for the case under consideration. Such a benchmark can only be provided by review of large numbers of cases reported by experienced clinicians giving the details of techniques. Systematic reviews, with their strict criteria, are considered by some to be the gold standard, but do they fit the purpose? In the real world of clinical practice, the effectiveness and appropriateness of PDT for a given case of cancer does not always, or even often, coincide with systematic review findings. Systematic reviews 
are more often based on controlled clinical trials and statistical significance rather than the clinical relevance in case series and observational studies or small-scale clinical trials compiled by specialist clinicians engaged in PDT. This fact becomes abundantly clear when one with a background of experience, involvement, and clinical skills looks at some of the published systematic reviews and their conclusions. ${ }^{24}$

Some of the existing systematic reviews in PDT have not been able to validate PDT for almost any clinical situation in oncology, despite many thousands of publications concerned with clinical trials, case series, and observational studies performed by experienced clinicians of repute in their specialties. ${ }^{24,25}$ In the face of such a discrepancy, clinicians must carry on with their duty of care and treat patients with PDT when, according to their experience or that of their peers, the treatment can help.

We have reviewed a large number of publications related to the use of PDT in different cancers, empirically but rationally placing them into three league tables according to the following criteria:

- Clinical effectiveness of PDT related to the particular type of cancer as judged by the results portrayed in a publication

- Standardization of the methodology of PDT used in a given cancer

- Reproducibility of results by different clinicians using an established methodology for the type of cancer under the review

- Number of patients and publications for a given cancer in which PDT was used

In reviewing publications for each of the above parameters, we allocated a grade from $1(+)$ to $3(+++)$ points: where $1(+)$ was the lowest, and the $3(++++)$, the highest.

The aim of this compilation was to see at a glance the current status and relative usage of PDT in a given type of cancer within the overall PDT in oncology.

\section{Results of the Review}

Based on the above criteria and parameters, we identified groups of cancer types and based on their scores placed them in three leagues represented in -Tables 3, 4, and 5.

\section{League I}

There are five types of cancers in this league: skin, lung, head and neck, Barrett's esophagus, and esophageal. From a clinical point of view, the methodology is in place for all these cancers, and there is a consensus of "how to do it" agreed upon by specialist physicians and surgeons engaged in practice.

\section{Skin Cancers and Precancerous Lesions}

Skin tumors were the subject of initial experiments of PDT in humans. The reasons are principally related to ease of application, notably in the illumination method, feasibility of monitoring progress, and assessing the results.

Many skin cancers are surgically excised, and surgery is still the treatment of choice and an attractive option for patients. However, for those with multiple lesions and/or with tumors in specific locations, such as the face, the alternative use of PDT appears more appealing to many. Also, it is generally agreed that for the immunosuppressed patient (organ transplant recipients, for example), those with a lesion near the orbit, and cases with Gorlin syndrome, PDT has more to offer than surgery. ${ }^{26,27}$

PDT in skin cancers other than melanomas has generated $\sim 900$ publications, many based on studies within controlled clinical trial protocols, with several books and a few guidelines. ${ }^{28,29}$ Photofrin and ALA or its derivative, methyl aminolevulinate, are the main PSs in use in Europe and North America. In other countries, notably China, the equivalent homemade formulation is used. The main skin cancers and procancers for which PDT has received approval in many of countries are:

- Actinic keratosis, with response rates between 75 and $89 \%$ with topical ALA PDT ${ }^{30-32}$

- Bowen disease (in situ squamous cell carcinoma), with complete response of 80 to $100 \%^{33,34}$

- Basal cell carcinoma, with complete response of 80 to 90 and recurrence rate of $\sim 10 \%$ at 5 years ${ }^{34-36}$

- Multiple basal cell carcinoma within Gorlin syndrome

In many patients, more than one treatment session will be required.

Many of the studies related to PDT in dermatologic cancers have been controlled clinical trials involving ALA or methylALA versus other standard methods; PDT was found to have better all-round results and cosmesis.

In one randomized study of PDT versus surgery, immediate results related to clinical response were equal but there was no recurrence in the surgery group whereas the PDT group had a recurrence rate of $\sim 10 \%$ at 1-year follow-up.

Table 3 League I PDT clinical classification

\begin{tabular}{|l|l|l|l|l|}
\hline PDT indications & Initial studies & Reproducibility & Publications & Method \\
\hline Skin & +++ & +++ & +++ & +++ \\
\hline Head and Neck/ENT & +++ & ++ & +++ & ++ \\
\hline Lung Ca. & +++ & +++ & +++ & +++ \\
\hline Barrett's esophagus & +++ & +++ & ++ & ++ \\
\hline Esophageal Ca. & +++ & +++ & +++ & +++ \\
\hline
\end{tabular}

Abbreviations: Ca, cancer; ENT, ear, nose, and throat; PDT, photodynamic therapy. 
Table 4 League II PDT clinical classification

\begin{tabular}{|l|l|l|l|l|}
\hline PDT indications & Initial studies & Reproducibility & Publications & Method \\
\hline Cholangiocarcinoma & ++ & $+I++$ & + & $+I++$ \\
\hline Mesothelioma & ++ & + & + & + \\
\hline Brain tumors & ++ & ++ & + & + \\
\hline Urology (prostate, bladder) & + & -+ & + & + \\
\hline
\end{tabular}

Abbreviation: PDT, photodynamic therapy.

$-=$ none; $-+=$ none or a small number less than 10 publications.

Table 5 League III PDT clinical classification

\begin{tabular}{|l|l|l|l|l|l|}
\hline PDT indications & Initial studies & Reproducibility & Publications & Method & Remarks \\
\hline $\begin{array}{l}\text { Gynecology } \\
\text { CIN }\end{array}$ & ++ & & & & \\
VIN & ++ & + & $+1++$ & + & - \\
$\quad$ Ovary & + & ++ & + & + & Experimental only \\
\hline $\begin{array}{l}\text { Breast } \\
\quad \text { Primary } \\
\text { Chest wall recurrence }\end{array}$ & + & - & & - & \\
\hline Pancreas & -+ & - & + & - & Laboratory/experimental (see text) \\
\hline Intraperitoneal & + & - & + & + & \\
\hline
\end{tabular}

Abbreviations: CIN, cervical intraepithelial neoplasia, VIN, vulvar intraepithelial neoplasia; PDT, photodynamic therapy.

$-=$ none; $-+=$ none or a small number less than 10 publications.

Nevertheless, patient satisfaction and cosmetic results were superior in PDT compared with surgery. ${ }^{37}$

\section{Head and Neck}

Head and neck cancers are a diverse group of tumors whose management falls within several specialties, notably maxillofacial, otorhinolaryngology, and plastic surgery. Some 550,000 cases of squamous cell carcinoma of the head and neck are globally diagnosed annually with 300,000 deaths.

Standard treatment for head and neck cancers is surgery, radiotherapy, and chemotherapy. Nevertheless, there is still a need for a reliable local therapy to fill the gap in the standard methods of therapies for cases of recurrence after surgery, or when chemoradiation may not be indicated or has been used without success. In the early stages of the disease, surgery can confer long survival amounting to cure of the disease, with 5year survival of over $80 \%$. The overall survival is 40 to $50 \%{ }^{38}$

PDT has been used extensively in the oral cavity, pharynx, and larynx since the early 1980 s. $^{39}$ During the past 30 years, many hundreds of patients have been treated in various organs within the anatomical field of the head and neck. Photofrin as well as meso-tetraphenyl chlorine (MTHPC) and ALA have been employed by different investigators in many hundreds of studies. ${ }^{40}$ Indications for PDT in these cancers have been classified into:

1. Treatment with curative intent applicable for those with an early cancer ${ }^{41-43}$

2. Treatment of locally advanced cases where the aim is to offer patients a better quality of existence within the limited lifespan that they have ${ }^{44}$
3. Use as a neoadjuvant therapy and intraoperatively as an aid to a more complete resection

4. Treatment of local recurrence

Clinical studies have been conducted using principally Photofrinorm mTHPC (Foscan). The dose and methodology for each of these have been standardized and are well documented in the literature. ${ }^{45,46}$

\section{Lung Cancer}

Lung cancer claims nearly 1.4 million deaths per year global$\mathrm{ly}^{38}$ and surgical resection is established as its primary treatment; the long awaited use of surgery for lung cancer materialized in 1933 by Graham and Singer. ${ }^{47}$ Over the next 25 years, with a growing understanding of the oncological aspects of lung cancer, a rational attitude of selection of patients was adopted. Although surgery is considered the first modality of treatment, it can only be offered to a minority; at most, $20 \%$ of cases have cancer found early enough to offer $70 \%$ long-term survival. In effect, at presentation, between 80 and $85 \%$ of patients with lung cancer are in an advanced stage of the disease and unsuitable for surgery.

In recent years, apart from radiotherapy and chemotherapy (which are standard treatment), several other therapies, including PDT, have entered into the arena of lung cancer treatment. The objectives of PDT in lung cancer are to achieve one or more of the following: downstage the tumor, effectively acting as a neoadjuvant therapy ${ }^{48-51}$; provide a good palliation with added survival benefit in advanced 
diseases ${ }^{52,53}$; offer complete response for a long period in early cases $^{54-57}$; treat local recurrence. ${ }^{57}$

For 70 to $80 \%$ of treated patients, PDT confers a significant improvement of exercise tolerance with parallel increase in ventilation, represented by forced vital capacity and forced expiratory volume in 1 second values and elimination of hemoptysis. $^{58,59}$

In cases with early cancer, the aim of treatment is to destruct the cancer at its in situ stage of development, coupled with a long-term complete response and clearance. Review of the literature shows that between 60 and $70 \%$ of patient with early (stage 1a) cancer survive 5 years or more.

The discovery of in situ endobronchial cancer and early detection of the local recurrence are greatly assisted by autofluorescence bronchoscopy, which can provide localization of the lesion in cases where the lesion may not be visible by the usual white light bronchoscopy. ${ }^{60-62}$

Over 95\% of PDTs in lung cancer are performed bronchoscopically for central-type lung cancer and usually for nonsmall cell lung cancer histology. Bronchoscopic PDT is performed in the usual two steps, that is, systemic presensitization followed by an interval of illumination using the bronchoscope's instrumental channel to accommodate the laser delivery fiber. Bronchoscopic PDT uses Photofrin (porfimer sodium) or equivalent porphyrin-derived formulations.

PDT is also used for peripheral lung cancer, for which there is limited experience. In such cases, the illumination is performed using imaging methods to localize the tumor. ${ }^{63}$ An alternative method is to use a thoracoscope to visualize the tumor and place the light delivery fiber under direct vision. ${ }^{64}$

\section{Barrett's Esophagus and Esophageal Cancer}

Barrett's esophagus refers to a condition where a variable length of the normal squamous cell mucosa of the lower esophagus, above the esophagogastric junction, is covered by columnar cell mucosa of gastric and/or intestinal-type mucosa (metaplastic mucosa). Such metaplastic mucosa is subject to dysplastic changes, which are graded as high, moderate, and low. There is a general consensus that patients with Barrett's esophagus, particularly those with high-grade dysplasia (HGD), are at risk of developing cancer. The most important issue is the relationship between HGD and adenocarcinoma of the esophagus, which has been debated for almost 25 years with no sign of it abating. Many, including the senior author of this article, believe that some $40 \%$ of HGDs are already an early cancer or are found concomitantly with a cancer. ${ }^{65-67}$ There are also issues related to interobserver variation of diagnosis of HGD versus carcinoma in situ, as well as the liability of biopsy samples being representative of the whole metaplastic extent. ${ }^{68,69}$ We and several other surgical teams believe that in patients with long segment $(>10 \mathrm{~cm})$ metaplastic mucosa, particularly those with a stricture, surgery should receive serious consideration. ${ }^{65-67}$

Some surgeons and several patients consider that the risk of surgery with its morbidity and mortality is prohibitive to their acceptance of radical operation. In such cases, interventional endoscopy methods are an alternative treatment option. PDT, with its good track record and several hundreds of publications based on clinical trials, occupies a prominent if not the most prominent place among endoscopic methods. Used alone or with other minimally invasive methods, such as endoscopic mucosal resection, PDT has been shown to eliminate Barrett's mucosa, destroy the HGD, and potentially reduce the rate of progression to adenocarcinoma. ${ }^{70-72}$

\section{Cancer of the Esophagus}

Cancer of the esophagus affects over 450,000 individuals per year worldwide with 400,000 deaths. ${ }^{73}$ Over $50 \%$ of cases are surgically unresectable at diagnosis, and $80 \%$ are oncologically at a stage for which surgery cannot be undertaken with curative intent. Surgery, radiotherapy, and chemotherapy are the standard therapies. For an early stage 1 cancer, surgical resection can achieve a 70 to $75 \% 5$-year or greater survival. ${ }^{74,75}$

McCaughan et al used PDT for cancer of the esophagus in $1983 .{ }^{76}$ Since then, PDT has been employed in many thousands of patients for early and locally advanced stages of cancers. PDT is used in esophageal cancer for patients with locally advanced intraluminal tumors. These bulky, locally obstructive tumors cause serious symptoms. The aim of PDT is the relief of dysphagia, amelioration of nutrition, and improvement of quality of life. These objectives are achieved in the majority of PDT-treated cases. ${ }^{77-80}$ PDT is also used in patients with early mucosal tumors unsuitable for surgery. Long-term survival of 5 or more years is achieved in 50 to $60 \% .^{81,82}$

\section{League II}

There are four types of cancer within this league: cholangiocarcinomas, malignant pleural mesotheliomas, brain tumors, and urologic (prostate and bladder) tumors.

\section{Cholangiocarcinoma}

Cholangiocarcinoma is attended by distressing symptoms and overall poor outcome irrespective of therapy because of difficulty in diagnosing the condition in an early stage of its development. The natural history of the disease is a gradual deterioration of liver function and death by hepatic failure or cholangitis caused by biliary obstruction.

Surgery is the treatment of choice in early stages of the disease and can be accompanied by long survival or cure in 20 to $30 \%$ of cases. ${ }^{83}$ Chemoradiation is used as an adjunct to surgery.

In 1991, McCaughan et al advocated the use of PDT for the extrahepatic biliary system, ${ }^{84}$ and in 1998 Ortner et al published the first series of nine patients showing that PDT was effective in restoring biliary drainage and improving quality of life in patients with nonresectable cholangiocarcinomas who had previous insertion of stent. ${ }^{85}$ Since then, several studies have been conducted, all based on the use of a plastic or metal stent in combination with PDT. In clinical trials, different authors have shown better quality of life and longer survival of patients who received PDT combined with stent versus those having stent alone. ${ }^{86-89}$ Photofrin (porfimer sodium) has been used by the majority of investigators. However, meso-tetra-hydroxyphenyl chlorine (Foscan) has also been employed. ${ }^{88}$ 


\section{Malignant Pleural Mesothelioma}

Malignant pleural mesothelioma is a tumor that affects the pleural membrane of the lung. It grows slowly but relentlessly to encase the lung with a rigid crust of cancer, restricting pulmonary ventilation leading to respiratory failure and death. Surgery, in one form or another, is an ingredient of treatment. In its simplest form, surgery provides drainage of fluid (pleural effusion). Its most complex format is the operation known as extrapleural pneumonectomy within a chemoradiation protocol of a trimodality treatment, ${ }^{90,91}$ which has high mortality and morbidity but a better survival outcome. An alternative to extensive extrapleural pneumonectomy is the lung-sparing surgery of radical pleurectomy with adjuvant radiotherapy with or without chemotherapy with cytoreductive operation (decortication) added as local therapy. ${ }^{92}$ PDT in malignant pleural mesothelioma has been tried since the early 1990 s and is still facing several challenges such as finding a suitable PS and an optimal method of illumination within the thoracic cavity and light dosimetry. ${ }^{93}$ Review of the literature indicates 13 clinical publications concerned with a total of 298 patients. ${ }^{94}$ The main PS used for malignant pleural mesothelioma is Photofrin (porfimer sodium). In recent years, radical pleurectomy combined with intracavitary Photofrin PDT has shown encouraging results. ${ }^{95}$

\section{Brain Tumors}

Brain tumors are rare, with an incidence of $\sim 6 / 100,000$ persons, and are responsible for $3 \%$ of all cancer deaths. ${ }^{38}$ Without treatment, the survival averages $<40$ weeks; with surgery and chemoradiation, there is improvement to about 52 weeks. ${ }^{96}$ PDT for brain tumors started in the 1980 s, ${ }^{97}$ and despite considerable preclinical and clinical research, many challenges remain due to the histologic differences and patterns of infiltration of neoplastic cells within the mass of normal cells; lack of a PS, which is endowed with specific ability to localize in the tumor; and lack of appropriate light and delivery devices suitable for brain tissue, which also match the absorption band of the specific PS.

Some of these issues are currently subject to investigation. ${ }^{98-102}$ Current clinical practice and research are focused on optimization of light and PS characteristics and dose parameters, ${ }^{101,102}$ use of PDT as an adjunct to surgery and/ or radiotherapy to mop up residual tumor and treat recurrent lesions, ${ }^{103}$ use of PDT associated with/or in combination with surgery, and fluorescence diagnosis and fluorescence-guided surgery using the principle of PDR. ${ }^{104-106}$

\section{Urologic Cancer}

\section{Prostate Cancer}

Surgery, radiotherapy, and external beam radiotherapy or brachytherapy schedule, chemotherapy, and hormones are the standard primary treatments for prostate cancer. They are used individually, in concert, or in sequence depending on several factors including tumor characteristics, age, lifestyle, and patient choice. ${ }^{107}$ Patient participation in decision making is particularly important in prostate cancer, because some of the treatments may result in unwanted effects such as incontinence and erectile dysfunction not compatible with the patient's expectation of posttreatment quality of life. These factors are relevant in relation to the emergence of several focal therapy methods. ${ }^{107-109}$ PDT, as one of several focal therapies, has the distinct advantage in being cancerspecific and target-oriented. Many of the focal therapy methods rely on image guidance and operate on the basic principle of indiscriminate destruction of the image of the tumor and the visual impression of the lesion. ${ }^{110}$ Although PDT does need image-guided localization for illumination, it has an additional inherent guidance mechanism that is wavelengthspecific to seek, find, and destroy the cancer. Some issues, however, have adversely affected the move from preclinical advances to the clinical practice of PDT for prostate cancer, namely appropriate PS, suitable light and its delivery device, and assessing the result of therapy. These require coordinated preclinical and clinical research.

At a clinical level, three types of PS have been explored and investigated in pilot and phase I and II trials: mTHPC/ Foscan, ${ }^{111,112}$ motexafin lutetium, ${ }^{113}$ and vascular-targeted PS, TOOKAD. ${ }^{114,115}$ TOOKAD is currently the focus of attention and continuing clinical trials in several centers. Preliminary results are encouraging both in respect to localization of the PS in the prostate gland, its short administration-illumination interval, and the lack of skin photosensitivity reaction.

\section{Bladder Cancer}

The "niche" indication of PDT in bladder cancer is superficial transitional cell cancer (TCC) and carcinoma in situ (CIS) and began with the use of HPD in the 1980s. ${ }^{116}$ The use of Photofrin was then followed for patients with widespread refractory TCCs and CISs. ${ }^{117,118}$ With the availability of the ALA prodrug, the topical intravesical method was employed for whole (inner) bladder PDT in patients with widespread bladder TCC and CIS, thus avoiding the inconvenience of systemic photosensitization. ${ }^{119}$ The response rates for systemic and topical methods were similar, with 50 to $60 \%$ complete response for a duration of $\sim 3$ years. In recent years, the diagnosis of TCC and CIS has been potentiated by the use of photodiagnosis using ALA- (or its derivatives) assisted fluorescence cystoscopy. ${ }^{120}$

\section{League III}

There are four cancers in this league: gynecologic cancers, breast cancer, cancer of the pancreas, and intraperitoneal cancers.

\section{Gynecologic Cancers}

\section{Cervical Intraepithelial Neoplasia}

Cervical cancer is the second most common cancer in women and cervical intraepithelial neoplasia is its precursor. The condition is directly related to some types of human papilloma virus infection; therefore, the assessment of any method of therapy should consider the effect on elimination of the virus as well. Standard therapies for cervical intraepithelial neoplasia are cold knife conization, loop electrosurgery, thermal laser, and cryotherapy. Short term, these treatments 
are satisfactory but have inconveniences such as pain, postoperative bleeding, and sequelae including stricture, cervical insufficiency, infertility, and difficulty of natural delivery. PDT has been used as an alternative treatment. Photofrin and topical ALA and its derivative hexaminolevulinate have been used successfully by several clinicians with favorable results. ${ }^{121-123}$ PDT results at short term are comparable with cold knife conization (91 and 100\%, respectively). Similar results are obtained in relation to human papillomavirus clearance. However, PDT is not attended by the complications and the sequelae of conization and other standard treatments, and it can be repeated.

\section{Vulvar Intraepithelial Neoplasia}

Vulvar intraepithelial neoplasia is a precancerous skin lesion of the vulva and is attended by symptoms of discomfort, local irritation, pruritus, and interference with sexual function. Standard treatments are thermal $\left(\mathrm{CO}_{2}\right)$ laser and application of 5-fluouracil and/or imiquimod (imunoresponse modifier). The treatment of vulvar intraepithelial neoplasia with PDT is currently being investigated, and topical ALA PDT is the most frequently used method. Improvement with relief of symptoms is reported in nearly $90 \%$ of patients, ${ }^{124-126}$ but recurrence rates are as high as $90 \%$, which means repeat treatment will be required. ${ }^{124}$ After multiple sessions, ALA PDT can achieve long-term results lasting several months and years in some $60 \%$ of patients. Although other systemic PSs have been used in a small number of patients, ${ }^{127}$ the results are not consistent or sufficiently reproducible and there is the inconvenience of skin photosensitivity.

\section{Ovarian Cancer}

The standard treatment for many ovarian cancers is maximal cytoreductive surgery and chemotherapy. Fluorescence ALA visualization techniques (photodiagnosis) is helpful in the staging as well as in monitoring the effects of laparoscopic treatment. ${ }^{128}$ The method can also detect disseminated microfoci during surgery. The effectiveness of PDT with Photofrin and ALA in treating ovarian cancer has been evaluated in two studies. ${ }^{129,130}$ These were focused, however, more of the nature of feasibility rather than for evaluation of efficacy.

\section{Breast Cancer}

Despite a considerable amount of laboratory preclinical ex vivo and in vivo animal work, PDT in breast cancer has not moved to the clinical arena. The search for an appropriate PS, its matching light, and optimal methodology goes on. There are, nevertheless, some pilot studies on chest wall recurrence of breast cancer. ${ }^{131-134}$ In such cases, it is important to assess the extent of the lesion both in surface area and the depth of invasion. It is also necessary to take into account previous radiotherapy and make appropriate provision for the skin resurfacing of the area necrosed by PDT. The clinical work at this time is in the domain of experimentation and salvage.

\section{Pancreatic Cancer}

Some $20 \%$ of patients with adenocarcinoma, the main pancreatic cancer cell type, may be diagnosed at an early stage.
Surgery has a potential 25 to $30 \% 5$-year survival. ${ }^{135}$ The other $80 \%$ of patients have either metastases or locally advanced inoperable disease at presentation. Theoretically, PDT can debulk large locally advanced tumors and eradicate smaller ones. Most of the current knowledge is derived from laboratory and experimental in vivo animal work. A handful of patients treated within experimental protocols convey useful practical information. However, there are several challenges in applying PDT to pancreatic cancer. These include appropriate PS, light parameters, and method of access for illumination and the appropriate devices.

Considerable laboratory and preclinical studies are needed to align the required parameters. In two studies in a small number of patients, the PS was verteporfin and percutaneous computed tomography or endoscopic ultrasonography provided access for illumination. ${ }^{136,137}$

\section{Intra-abdominal Photodynamic Therapy}

The abdominal cavity accommodates many organs and structures, each of which can be the seat of a malignant tumor. The geometry of the abdominal cavity and its peritoneal lining is such that many neoplasms will be disseminated transcoelomically to other organs. Production of fluid (effusion) as exudate or transudate will also assist the malignant cell to navigate and disseminate through the abdominal cavity. In many such circumstances, PDT can theoretically assist surgery in the process of debulking as well as destruction of macro- and microfoci. Initial feasibility work has been performed in the 1990s. ${ }^{138}$ However, numerous issues require preclinical work, some of which are in progress at the present.

The tools of PDT for such a venture are the development of a PS with specific targeting capabilities and high ratio of localization in the tumor as compared with normal structures and the design of devices to uniformly distribute light to the outer layer of the organs without deep structural damage to healthy tissues. Recent developments in nanotechnology and advances in the manufacturing of optical fabrics are two areas that will assist progress in this domain. ${ }^{139-142}$

\section{Morbidity and Mortality of Photodynamic Therapy}

PDT-related mortality is extremely rare and usually follows an accidental overzealous illumination or lack of appreciation of the anatomical or pathologic area of the treated target. The morbidity of PDT should be considered for systemic and topical PDT separately.

\section{Systemic PDT}

The commonest unwanted effect of systemic PDT is the photosensitivity skin reaction, which in one review was reported to occur in 4 to $28 \%$ of cases. ${ }^{143}$ However, the rate is variable and depends on the type of PS, the experience of the PDT team, and the number of procedures undertaken by a team. Inflammation/ulceration at the site of IV administration due to extravasation of the PS is rare to nonexistent in expert hands. Hemorrhage in the case of infiltration by tumor of a blood vessel wall followed by PDT necrotic erosion is occasionally reported, which is more a matter of accident or miscalculated light dose. Perforation of a tubular structure 
or a body cavity due to overdosed illumination is also rare (less than $2 \%$ ). Stricture of tubular organs due to scarring can occur in $6 \%$ of esophageal cases but usually yields with dilatation.

Complications in specific sites include hemorrhage in vascular lesions, respiratory complications in tracheobronchial PDT, and pain in upper gastrointestinal PDT.

\section{Topical PDT}

Pain is the commonest complication of topical PDT and is much more prominent when ALA is used in skin conditions affecting external genitalia (for example, vulvar intraepithelial neoplasia). There are various ways to reduce the intensity of pain but in some extensive lesions, local or even general anesthetic may have to be considered. Ulceration, followed by scarring, can occur in some cases. Rarely, infection can occur in an ulcerating wound.

On the whole, most of the complications of PDT are avoidable and preventable. Complications in specific sites require the attention of an appropriate specialist related to the site.

\section{Conclusion}

The science of PDT has been around for over 100 years, and its clinical practice for cancer treatment has been in existence at least for 35 years. During the past 20 years, the science of PDT has taken a giant leap, far outstripping clinical application. It is unfortunate that PDT's clinical progress has not been as dramatic as its science. Much of the science of PDT in biology, photobiology, and chemistry departments of universities across the world is in fact a continuation of PDR, and it is unrealistic to consider that more than a few will ever reach clinical practice.

Clinical PDT initially began by following the footprints established through earlier laboratory and experimental work. Serious clinical studies in the 1980s were undertaken in common cancers, particularly those that most frequently occur, and in cases in which the illumination was technically easily performed. This fact is reflected in the current review, which places them in PDT league I. The methodology of PDT in all of the cancers in this league is well established and well tried and tested.

PDT in many of the cancers of leagues II and III is shown to be safe and effective in achieving its objective. However, the methodology and consistency of results require more work to increase their use.

What does PDT offer the surgeon?

- PDT is a safe and effective cancer modality treatment whose technique can easily be mastered by a specialist surgeon.

- In several cancers, PDT can be undertaken by endoscopic methods and is a routine undertaking for many surgeons. In the event of any complications, surgeons, by reason of training, are in a position to deal with the complications effectively.

- In patients with precancerous lesions, where surgery might involve a prohibitively risky undertaking, PDT can be an option and achieve long-lasting clearance.
- In patients with an early localized cancer, PDT can achieve long-term complete clearance amounting to a cure. Examples of these are presented throughout this review.

- In patients with locally advanced disease with symptoms related to the volume of the tumor, PDT can be used for palliation and in some cases can confer a survival benefit.

- PDT can be used together with other standard treatments including surgery.

- Fluorescence imaging, which is part and parcel of PDR, can assist the surgeon to pick up residual tumor or to outline neoplastic infiltration at the margin of resection, thus ensuring a complete excision.

Based on this review and upon personal experience, we believe that future progress in clinical PDT must consider it within the multimodal cancer treatment methods and not as a monotherapy, which thus far has mostly been the case.

The medical profession has not been very welcoming in recent years in acknowledging the usefulness of PDT, partially because of financial constraints. By including PDT within a multimodality setting, we believe it will be easier to develop protocols of studies/clinical trials to the benefit of many cancer patients.

\section{Acknowledgment}

The authors would like to acknowledge the help and patience of Mrs. Janet Melvin in the production of this manuscript.

\section{References}

1 Raab O. Uber die Wirkung Fluorecierenden Stoffe auf Infusorien. Z Biol 1904;30:524-546

2 von Tappeiner H, Odlabauer JA. Uber die Wirkung der photodynamischen (fluorescierenden) Stoffe auf Protozoen und Enzyne. Dtsch Arch Klin Med 1904;80:427-487

3 von Tappeiner H, Jesionek H. Therapetische Versuche mit fluoreszierenden Stoffen. Munch Med Wochenschr 1903;50: 2042-2044

4 von Tappeiner JH. Zur Behand lung der Hautcarcinome mit fluoreszierenden Stoffen. Dtsch Arch Klin Med 1905;82:223-226

5 Moghissi K, Stringer MR, Dixon K. Fluorescence photodiagnosis in clinical practice. Photodiagn Photodyn Ther 2008;5(4):235-237

6 Krammer B, Malik Z, Pottier R, Stepp H. Principles of ALA-based FD. In: Pottier R, et al, eds. Photodynamic Therapy with ALA: A Clinical Handbook. London, UK: RSC Publication; 2006:51

7 Eljamel MS. Fluorescence image-guided surgery of brain tumors: explained step-by-step. Photodiagn Photodyn Ther 2008;5(4): 260-263

8 Lipson RL, Baldes EJ, Olsen AM. Hematoporphyrin derivative: a new aid for endoscopic detection of malignant disease. J Thorac Cardiovasc Surg 1961;42:623-629

9 Lipson RL, Baldes EJ, Gray MJ. Hematoporphyrin derivative for detection and management of cancer. Cancer 1967;20(12): 2255-2257

10 Dougherty TJ, Kaufman JE, Goldfarb A, Weishaupt KR, Boyle D, Mittleman A. Photoradiation therapy for the treatment of malignant tumors. Cancer Res 1978;38(8):2628-2635

11 Kessel D, Dougherty TJ, eds. Porphyrin Photosensitisers. New York, NY: Plenum Press; 1981 
12 Kennedy JC, Pottier RH. Endogenous protoporphyrin IX, a clinically useful photosensitizer for photodynamic therapy. J Photochem Photobiol B 1992;14(4):275-292

13 Allison RR, Downie GH, Cuenca R, Hu XH, Childs CJ, Sibata CH. Photosensitizers in clinical PDT. Photodiagn Photodyn Ther 2004; 1(1):27-42

14 Mang TS. Lasers and light sources for PDT: past, present and future. Photodiagn Photodyn Ther 2004;1(1):43-48

15 Castano AP, Demidova TN, Hamblin MR. Mechanisms in photodynamic therapy: part two-cellular signaling, cell metabolism and modes of cell death. Photodiagn Photodyn Ther 2005;2(1): $1-23$

16 Oleinick NL, Nieminen AL, Chiu SM. Cell killing by photodynamic therapy. In: Hamblin MR, Mroz P, eds. Advances in Photodynamic Therapy. Norwood, MA: Artec House; 2008:115-133

17 Allison RR, Moghissi K. Oncologic photodynamic therapy: clinical strategies that modulate mechanisms of action. Photodiagn Photodyn Ther 2013;10(4):331-341

18 Firczuk M, Nowis D, Gołąb J. PDT-induced inflammatory and host responses. Photochem Photobiol Sci 2011;10(5):653-663

19 Garg AD, Nowis D, Golab J, Agostinis P. Photodynamic therapy: illuminating the road from cell death towards anti-tumour immunity. Apoptosis 2010;15(9):1050-1071

20 Ethirajan M, Saenz C, Gupta A, et al. Photosensitizers for photodynamic therapy and imaging. In: Hamblin MR, Pawet M, eds. Advances in Photodynamic Therapy. Norwood, MA: Artec House; 2008:13-39

21 Huang Z. Photodynamic therapy in China: over 25 years of unique clinical experience. Part One-History and domestic photosensitizers. Photodiagn Photodyn Ther 2006;3(1):3-10

22 Sandell JL, Zhu TC. A review of in-vivo optical properties of human tissues and its impact on PDT. J Biophotonics 2011;4(11-12): 773-787

23 Fodor L, Elman M, Ullmann Y. Light tissue interaction. In: Aesthetic Applications of Intense Pulsed Light. London, UK: Springer-Verlag Publishers; 2011

24 Fayter D, Corbett M, Heirs M, Fox D, Eastwood A. A systematic review of photodynamic therapy in the treatment of pre-cancerous skin conditions, Barrett's oesophagus and cancers of the biliary tract, brain, head and neck, lung, oesophagus and skin. Health Technol Assess 2010;14(37):1-288

25 Gao F, Bai Y, Ma SR, Liu F, Li ZS. Systematic review: photodynamic therapy for unresectable cholangiocarcinoma. J Hepatobiliary Pancreat Sci 2010;17(2):125-131

26 Wang I, Bauer B, Andersson-Engels S, Svanberg S, Svanberg K. Photodynamic therapy utilising topical delta-aminolevulinic acid in non-melanoma skin malignancies of the eyelid and the periocular skin. Acta Ophthalmol Scand 1999;77(2):182-188

27 Loncaster J, Swindell R, Slevin F, Sheridan L, Allan D, Allan E. Efficacy of photodynamic therapy as a treatment for Gorlin syndrome-related basal cell carcinomas. Clin Oncol (R Coll Radiol) 2009;21(6):502-508

28 Braathen LR, Szeimies RM, Basset-Seguin N, et al; International Society for Photodynamic Therapy in Dermatology. Guidelines on the use of photodynamic therapy for nonmelanoma skin cancer: an international consensus. International Society for Photodynamic Therapy in Dermatology, 2005. J Am Acad Dermatol 2007; 56(1):125-143

29 Morton C, Szeimies RM, Sidoroff A, et al. European Dermatology Forum Guidelines on topical photodynamic therapy. Eur J Dermatol 2015; June 12 (Epub ahead of print)

30 Kennedy JC, Pottier RH, Pross DC. Photodynamic therapy with endogenous protoporphyrin IX: basic principles and present clinical experience. J Photochem Photobiol B 1990;6(1-2): 143-148

31 Piacquadio DJ, Chen DM, Farber HF, et al. Photodynamic therapy with aminolevulinic acid topical solution and visible blue light in the treatment of multiple actinic keratoses of the face and scalp: investigator-blinded, phase 3, multicenter trials. Arch Dermatol 2004;140(1):41-46

32 Morton C, Horn M, Leman J, et al. Comparison of topical methyl aminolevulinate photodynamic therapy with cryotherapy or fluorouracil for treatment of squamous cell carcinoma in situ: results of a multicenter randomized trial. Arch Dermatol 2006; 142(6):729-735

33 Morton CA, Whitehurst C, Moseley H, McColl JH, Moore JV, Mackie RM. Comparison of photodynamic therapy with cryotherapy in the treatment of Bowen's disease. Br J Dermatol 1996; 135(5):766-771

34 Salim A, Leman JA, McColl JH, Chapman R, Morton CA. Randomized comparison of photodynamic therapy with topical 5-fluorouracil in Bowen's disease. Br J Dermatol 2003;148(3):539-543

35 Basset-Seguin N, Ibbotson SH, Emtestam L, et al. Topical methyl aminolaevulinate photodynamic therapy versus cryotherapy for superficial basal cell carcinoma: a 5 year randomized trial. Eur J Dermatol 2008;18(5):547-553

36 Zeitouni NC, Shieh S, Oseroff AR. Laser and photodynamic therapy in the management of cutaneous malignancies. Clin Dermatol $2001 ; 19(3): 328-338$

37 Szeimies RM, Ibbotson S, Murrell DF, et al; Excilight Study Group. A clinical study comparing methyl aminolevulinate photodynamic therapy and surgery in small superficial basal cell carcinoma (8-20 mm), with a 12-month follow-up. J Eur Acad Dermatol Venereol 2008;22(11):1302-1311

38 Jemal A, Bray F, Center MM, Ferlay J, Ward E, Forman D. Global cancer statistics. CA Cancer J Clin 2011;61(2):69-90

39 Keller GS, Doiron DR, Fischer GU. Photodynamic therapy in otorhinolaryngology-head and neck surgery. Arch Otolaryngol 1985;111(11):758-761

40 Biel MA. Photodynamic therapy of head and neck cancers. Methods Mol Biol 2010;635:281-293

41 von Beckerath MP, Reizenstein JA, Berner AL, et al. Outcome of primary treatment of early laryngeal malignancies using photodynamic therapy. Acta Otolaryngol 2014;134(8):852-858

42 Ikeda H, Tobita T, Ohba S, Uehara M, Asahina I. Treatment outcome of Photofrin-based photodynamic therapy for T1 and T2 oral squamous cell carcinoma and dysplasia. Photodiagn Photodyn Ther 2013;10(3):229-235

43 de Visscher SA, Melchers LJ, Dijkstra PU, et al. mTHPC-mediated photodynamic therapy of early stage oral squamous cell carcinoma: a comparison to surgical treatment. Ann Surg Oncol 2013; 20(9):3076-3082

44 Biel M. Advances in photodynamic therapy for the treatment of head and neck cancers. Lasers Surg Med 2006;38(5):349-355

45 Allison RR, Sibata C, Gay H. PDT for cancers of the head and neck. Photodiagn Photodyn Ther 2009;6(1):1-2

46 Green B, Cobb AR, Hopper C. Photodynamic therapy in the management of lesions of the head and neck. Br J Oral Maxillofac Surg 2013;51(4):283-287

47 Graham EA, Singer JJ. Successful removal of an entire lung for carcinoma of the bronchus. JAMA 1933;101:13-17

48 Kato H, Konaka C, Ono J, et al. Preoperative laser photodynamic therapy in combination with operation in lung cancer. J Thorac Cardiovasc Surg 1985;90(3):420-429

49 Okunaka T, Hiyoshi T, Furukawa K, et al. Lung cancers treated with photodynamic therapy and surgery. Diagn Ther Endosc 1999;5(3):155-160

50 Ross PJr, Grecula J, Bekaii-Saab T, Villalona-Calero M, Otterson G, Magro C. Incorporation of photodynamic therapy as an induction modality in non-small cell lung cancer. Lasers Surg Med 2006; 38(10):881-889

51 Akopov A, Rusanov A, Gerasin A, Kazakov N, Urtenova M, Chistyakov I. Preoperative endobronchial photodynamic therapy improves resectability in initially irresectable (inoperable) locally advanced non small cell lung cancer. Photodiagn Photodyn Ther 2014;11(3):259-264 
52 LoCicero J III, Metzdorff M, Almgren C. Photodynamic therapy in the palliation of late stage obstructing non-small cell lung cancer. Chest 1990;98(1):97-100

53 Weimann TJ, Diaz-Jimenez JP, Moghissi K, et al. Photodynamic therapy (PDT) with Photofrin is effective in the palliation of obstructive endobronchial lung cancer; results of two randomized trials (abstract). Paper presented at: Proceedings of the 34th Annual Meeting of the American Society of Clinical Oncology; May 16-19, 1998; Los Angeles, CA

54 Ono R, Ikeda S, Suemasu K. Hematoporphyrin derivative photodynamic therapy in roentgenographically occult carcinoma of the tracheobronchial tree. Cancer 1992;69(7):1696-1701

55 Edell ES, Cortese DA. Photodynamic therapy in the management of early superficial squamous cell carcinoma as an alternative to surgical resection. Chest 1992;102(5):1319-1322

56 Kato H. Photodynamic therapy for lung cancer-a review of 19 years' experience. J Photochem Photobiol B 1998;42(2):96-99

57 Moghissi K, Dixon K, Thorpe JA, Stringer M, Oxtoby C. Photodynamic therapy (PDT) in early central lung cancer: a treatment option for patients ineligible for surgical resection. Thorax 2007; 62(5):391-395

58 McCaughan JS Jr, Williams TE. Photodynamic therapy for endobronchial malignant disease: a prospective fourteen-year study. J Thorac Cardiovasc Surg 1997;114(6):940-946, discussion 946-947

59 Moghissi K, Dixon K, Stringer M, Freeman T, Thorpe A, Brown S. The place of bronchoscopic photodynamic therapy in advanced unresectable lung cancer: experience of 100 cases. Eur J Cardiothorac Surg 1999;15(1):1-6

60 Lam S, Macaulay C, Leriche JC, Ikeda N, Palcic B. Early localization of bronchogenic carcinoma. Diagn Ther Endosc 1994;1(2):75-78

61 Horvath TA, Hirano T, Horvathova MD, et al. Autofluorescence (safe) bronchoscopy and p21/ki-67 immunostaining related to carcinogenesis. Photodiagn Photodyn Ther 2004;1(1):13-22

62 Moghissi K, Dixon K, Stringer MR. Current indications and future perspective of fluorescence bronchoscopy: a review study. Photodiagn Photodyn Ther 2008;5(4):238-246

63 Okunaka T, Kato H, Tsutsui H, Ishizumi T, Ichinose S, Kuroiwa Y. Photodynamic therapy for peripheral lung cancer. Lung Cancer 2004;43(1):77-82

64 Moghissi K, Dixon K, Thorpe JA. A method for video-assisted thoracoscopic photodynamic therapy (VAT-PDT). Interact Cardiovasc Thorac Surg 2003;2(3):373-375

65 DeMeester TR, Attwood SE, Smyrk TC, Therkildsen DH, Hinder RA. Surgical therapy in Barrett's esophagus. Ann Surg 1990; 212(4):528-540, discussion 540-542

66 Moghissi K, Sharpe DA, Pender D. Adenocarcinoma and Barrett's oesophagus. A clinico-pathological study. Eur J Cardiothorac Surg 1993;7(3):126-131

67 Sujendran V, Sica G, Warren B, Maynard N. Oesophagectomy remains the gold standard for treatment of high-grade dysplasia in Barrett's oesophagus. Eur J Cardiothorac Surg 2005;28(5): 763-766

68 Downs-Kelly E, Mendelin JE, Bennett AE, et al. Poor interobserver agreement in the distinction of high-grade dysplasia and adenocarcinoma in pretreatment Barrett's esophagus biopsies. Am J Gastroenterol 2008;103(9):2333-2340, quiz 2341

69 El Hallani S, Guillaud M, Korbelik J, Marginean EC. Evaluation of quantitative digital pathology in the assessment of Barrett esophagus-associated dysplasia. Am J Clin Pathol 2015;144(1): 151-164

70 Overholt BF, Wang KK, Burdick JS, et al; International Photodynamic Group for High-Grade Dysplasia in Barrett's Esophagus. Five-year efficacy and safety of photodynamic therapy with Photofrin in Barrett's high-grade dysplasia. Gastrointest Endosc 2007;66(3):460-468

71 Oliphant Z, Snow A, Knight H, Barr H, Almond LM. Endoscopic resection with or without mucosal ablation of high grade dyspla- sia and early oesophageal adenocarcinoma-long term follow up from a regional UK centre. Int J Surg 2014;12(11):1148-1150

72 Thorpe JA, Moghissi K. Photofrin PDT for Barrett's oesophagus with high-grade dysplasia. Photodiagn Photodyn Ther 2008;5(1): 36-37

73 American Cancer Society. Global Cancer Facts \& Figures. 2nd ed. Atlanta, GA: American Cancer Society; 2011

74 Moghissi K. Surgical resection for stage I cancer of the oesophagus and cardia. Br J Surg 1992;79(9):935-937

75 Berry MF, Zeyer-Brunner J, Castleberry AW, et al. Treatment modalities for T1N0 esophageal cancers: a comparative analysis of local therapy versus surgical resection. J Thorac Oncol 2013; 8(6):796-802

76 McCaughan JS Jr, Guy JT, Hawley P, et al. Hematoporphyrinderivative and photoradiation therapy of malignant tumors. Lasers Surg Med 1983;3(3):199-209

77 McCaughan JS Jr, Ellison EC, Guy JT, et al. Photodynamic therapy for esophageal malignancy: a prospective twelve-year study. Ann Thorac Surg 1996;62(4):1005-1009, discussion 1009-1010

78 Moghissi K, Dixon K, Thorpe JA, Stringer M, Moore PJ. The role of photodynamic therapy (PDT) in inoperable oesophageal cancer. Eur J Cardiothorac Surg 2000;17(2):95-100

79 Maier A, Tomaselli F, Gebhard F, Rehak P, Smolle J, Smolle-Jüttner FM. Palliation of advanced esophageal carcinoma by photodynamic therapy and irradiation. Ann Thorac Surg 2000;69(4): 1006-1009

80 Moghissi K. Where does photodynamic therapy fit in the esophageal cancer treatment jigsaw puzzle? J Natl Compr Canc Netw 2012;10(Suppl 2):S52-S55

81 Sibille A, Lambert R, Souquet JC, Sabben G, Descos F. Long-term survival after photodynamic therapy for esophageal cancer. Gastroenterology 1995;108(2):337-344

82 Moghissi K, Dixon K, Stringer M, Thorpe JA. Photofrin PDT for early stage oesophageal cancer: long term results in 40 patients and literature review. Photodiagn Photodyn Ther 2009;6(3-4): 159-166

83 Nakeeb A, Pitt HA, Sohn TA, et al. Cholangiocarcinoma. A spectrum of intrahepatic, perihilar, and distal tumors. Ann Surg 1996; 224(4):463-473, discussion 473-475

84 McCaughan JS Jr, Mertens BF, Cho C, Barabash RD, Payton HW. Photodynamic therapy to treat tumors of the extrahepatic biliary ducts. A case report. Arch Surg 1991;126(1):111-113

85 Ortner MA, Liebetruth J, Schreiber S, et al. Photodynamic therapy of nonresectable cholangiocarcinoma. Gastroenterology 1998; 114(3):536-542

86 Ortner ME, Caca K, Berr F, et al. Successful photodynamic therapy for nonresectable cholangiocarcinoma: a randomized prospective study. Gastroenterology 2003;125(5):1355-1363

87 Kahaleh M, Mishra R, Shami VM, et al. Unresectable cholangiocarcinoma: comparison of survival in biliary stenting alone versus stenting with photodynamic therapy. Clin Gastroenterol Hepatol 2008;6(3):290-297

88 Kniebühler G, Pongratz T, Betz CS, et al. Photodynamic therapy for cholangiocarcinoma using low dose mTHPC (Foscan $\left({ }^{\circledR}\right)$ ). Photodiagn Photodyn Ther 2013;10(3):220-228

$89 \mathrm{Lu} \mathrm{Y}$, Liu L, Wu JC, et al. Efficacy and safety of photodynamic therapy for unresectable cholangiocarcinoma: a meta-analysis. Clin Res Hepatol Gastroenterol 2015; June 9 (Epub ahead of print); doi: 10.1016/j.clinre.2014.10.015

90 Sugarbaker DJ, Wolf AS, Chirieac LR, et al. Clinical and pathological features of three-year survivors of malignant pleural mesothelioma following extrapleural pneumonectomy. Eur J Cardiothorac Surg 2011;40(2):298-303

91 Sugarbaker DJ, Richards WG, Bueno R. Extrapleural pneumonectomy in the treatment of epithelioid malignant pleural mesothelioma: novel prognostic implications of combined N1 and N2 nodal involvement based on experience in 529 patients. Ann Surg 2014;260(4):577-580, discussion 580-582 
92 Friedberg JS. Photodynamic therapy for malignant pleural mesothelioma. J Natl Compr Canc Netw 2012;10(Suppl 2): S75-S79

93 Moghissi K, Dixon K. Photodynamic therapy in the management of malignant pleural mesothelioma: a review. Photodiagn Photodyn Ther 2005;2(2):135-147

94 Moghissi K. Photodynamic therapy within global treatment of cancers for thoracic oncology. Royal Society of Chemistry Publication. In press

95 Friedberg JS, Culligan MJ, Mick R, et al. Radical pleurectomy and intraoperative photodynamic therapy for malignant pleural mesothelioma. Ann Thorac Surg 2012;93(5):1658-1665, discussion 1665-1667

96 Eljamel MS. PDT for brain cancer. In: Hamblin M, Mroz P, eds. Advances in Photodynamic Therapy: Basic, Translational and Clinical. Boston, MA, and London, UK: Artech House; 2008: 495-505

97 Perria C, Capuzzo T, Cavagnaro G, et al. Fast attempts at the photodynamic treatment of human gliomas. J Neurosurg Sci 1980;24(3-4):119-129

98 Kaye AH, Morstyn G, Brownbill D. Adjuvant high-dose photoradiation therapy in the treatment of cerebral glioma: a phase 12 study. J Neurosurg 1987;67(4):500-505

99 Stylli SS, Kaye AH, MacGregor L, Howes M, Rajendra P. Photodynamic therapy of high grade glioma-long term survival. J Clin Neurosci 2005;12(4):389-398

100 Marks PV, Belchetz PE, Saxena A, et al. Effect of photodynamic therapy on recurrent pituitary adenomas: clinical phase I/II trial -an early report. Br J Neurosurg 2000;14(4):317-325

101 Eljamel MS. Photodynamic assisted surgical resection and treatment of malignant brain tumours technique, technology and clinical application. Photodiagn Photodyn Ther 2004;1(1):93-98

102 Kostron H. Photodynamic diagnosis and therapy and the brain. Methods Mol Biol 2010;635:261-280

103 Muller P, Wilson B. Photodynamic therapy of brain tumours: postoperative "field fractionation". J Photochem Photobiol B 1991;9(1):117-119

104 Stummer W, Pichlmeier U, Meinel T, Wiestler OD, Zanella F, Reulen HJ; ALA-Glioma Study Group. Fluorescence-guided surgery with 5-aminolevulinic acid for resection of malignant glioma: a randomised controlled multicentre phase III trial. Lancet Oncol 2006;7(5):392-401

105 Stummer W, Novotny A, Stepp H, Goetz C, Bise K, Reulen HJ. Fluorescence-guided resection of glioblastoma multiforme by using 5-aminolevulinic acid-induced porphyrins: a prospective study in 52 consecutive patients. J Neurosurg 2000;93(6): 1003-1013

106 Eljamel MS, Goodman C, Moseley H. ALA and Photofrin fluorescence-guided resection and repetitive PDT in glioblastoma multiforme: a single centre phase III randomised controlled trial. Lasers Med Sci 2008;23(4):361-367

107 Moore CM, Pendse D, Emberton M. Photodynamic therapy for prostate cancer-a review of current status and future promise. Nat Clin Pract Urol 2009;6(1):18-30

108 Eggener SE, Coleman JA. Focal treatment of prostate cancer with vascular-targeted photodynamic therapy. ScientificWorldJournal 2008;8:963-973

109 Pastore AL, Palleschi G, Silvestri L, et al. Prospective randomized study of radiofrequency versus ultrasound scalpels on functional outcomes of laparoscopic radical prostatectomy. J Endourol 2013;27(8):989-993

110 Bomers JG, Sedelaar JP, Barentsz JO, Fütterer JJ. MRI-guided interventions for the treatment of prostate cancer. AJR Am J Roentgenol 2012;199(4):714-720

111 Nathan TR, Whitelaw DE, Chang SC, et al. Photodynamic therapy for prostate cancer recurrence after radiotherapy: a phase I study. J Urol 2002;168(4 Pt 1):1427-1432
112 Moore CM, Nathan TR, Lees WR, et al. Photodynamic therapy using meso tetra hydroxy phenyl chlorin (mTHPC) in early prostate cancer. Lasers Surg Med 2006;38(5):356-363

113 Patel H, Mick R, Finlay J, et al. Motexafin lutetium-photodynamic therapy of prostate cancer: short- and long-term effects on prostate-specific antigen. Clin Cancer Res 2008;14(15): 4869-4876

114 Azzouzi AR, Barret E, Moore CM, et al. TOOKAD( $\left({ }^{\circ}\right)$ Soluble vascular-targeted photodynamic (VTP) therapy: determination of optimal treatment conditions and assessment of effects in patients with localised prostate cancer. BJU Int 2013;112(6): 766-774

115 Azzouzi AR, Barret E, Bennet J, et al. TOOKAD® Soluble focal therapy: pooled analysis of three phase II studies assessing the minimally invasive ablation of localized prostate cancer. World J Urol 2015;33(7):945-953

116 Prout GR Jr, Lin CW, Benson R Jr, et al. Photodynamic therapy with hematoporphyrin derivative in the treatment of superficial transitional-cell carcinoma of the bladder. N Engl J Med 1987; 317(20):1251-1255

117 Nseyo UO, Shumaker B, Klein EA, Sutherland K; Bladder Photofrin Study Group. Photodynamic therapy using porfimer sodium as an alternative to cystectomy in patients with refractory transitional cell carcinoma in situ of the bladder. J Urol 1998;160(1):39-44

118 D'Hallewin MA, Baert L. Long-term results of whole bladder wall photodynamic therapy for carcinoma in situ of the bladder. Urology 1995;45(5):763-767

119 Waidelich R, Beyer W, Knüchel R, et al. Whole bladder photodynamic therapy with 5-aminolevulinic acid using a white light source. Urology 2003;61(2):332-337

120 Kriegmair M, Baumgartner R, Knüchel R, Stepp H, Hofstädter F, Hofstetter A. Detection of early bladder cancer by 5 -aminolevulinic acid induced porphyrin fluorescence. J Urol 1996;155(1): 105-109, discussion 109-110

121 Keefe KA, Tadir Y, Tromberg B, et al. Photodynamic therapy of high-grade cervical intraepithelial neoplasia with 5-aminolevulinic acid. Lasers Surg Med 2002;31(4):289-293

122 Bodner K, Bodner-Adler B, Wierrani F, et al. Cold-knife conization versus photodynamic therapy with topical 5 -aminolevulinic acid (5-ALA) in cervical intraepithelial neoplasia (CIN) II with associated human papillomavirus infection: a comparison of preliminary results. Anticancer Res 2003;23(2C):1785-1788

123 Soergel P, Wang X, Stepp H, Hertel H, Hillemanns P. Photodynamic therapy of cervical intraepithelial neoplasia with hexaminolevulinate. Lasers Surg Med 2008;40(9):611-615

124 Hillemanns P, Untch M, Dannecker C, et al. Photodynamic therapy of vulvar intraepithelial neoplasia using 5-aminolevulinic acid. Int J Cancer 2000;85(5):649-653

125 Fehr MK, Hornung R, Schwarz VA, Simeon R, Haller U, Wyss P. Photodynamic therapy of vulvar intraepithelial neoplasia III using topically applied 5-aminolevulinic acid. Gynecol Oncol 2001;80(1):62-66

126 Booth S, Poole D, Moghissi K. Initial experience of the use of photodynamic therapy (PDT) in recurrent malignant and premalignant lesions of the vulva. Photodiagn Photodyn Ther 2006; 3(3):156-161

127 Campbell SM, Gould DJ, Salter L, Clifford T, Curnow A. Photodynamic therapy using meta-tetrahydroxyphenylchlorin (Foscan) for the treatment of vulval intraepithelial neoplasia. Br J Dermatol 2004;151(5):1076-1080

128 Löning M, Diddens H, Küpker W, Diedrich K, Hüttmann G. Laparoscopic fluorescence detection of ovarian carcinoma metastases using 5-aminolevulinic acid-induced protoporphyrin IX. Cancer 2004;100(8):1650-1656

129 Hendren SK, Hahn SM, Spitz FR, et al. Phase II trial of debulking surgery and photodynamic therapy for disseminated intraperitoneal tumors. Ann Surg Oncol 2001;8(1):65-71 
130 Wakui M, Yokoyama Y, Wang H, Shigeto T, Futagami M, Mizunuma $\mathrm{H}$. Efficacy of a methyl ester of 5-aminolevulinic acid in photodynamic therapy for ovarian cancers. J Cancer Res Clin Oncol 2010;136(8):1143-1150

131 Khan SA, Dougherty TJ, Mang TS. An evaluation of photodynamic therapy in the management of cutaneous metastases of breast cancer. Eur J Cancer 1993;29A(12):1686-1690

132 Taber SW, Fingar VH, Wieman TJ. Photodynamic therapy for palliation of chest wall recurrence in patients with breast cancer. J Surg Oncol 1998;68(4):209-214

133 Cuenca RE, Allison RR, Sibata C, Downie GH. Breast cancer with chest wall progression: treatment with photodynamic therapy. Ann Surg Oncol 2004;11(3):322-327

134 Liu Y, Hou G, Zhang X, Liu JJ, Zhang S, Zhang J. A pilot randomized clinical study of the additive treatment effect of photodynamic therapy in breast cancer patients with chest wall recurrence. J Breast Cancer 2014;17(2):161-166

135 Trede M, Schwall G, Saeger HD. Survival after pancreatoduodenectomy. 118 consecutive resections without an operative mortality. Ann Surg 1990;211(4):447-458

136 Chan HH, Nishioka NS, Mino M, et al. EUS-guided photodynamic therapy of the pancreas: a pilot study. Gastrointest Endosc 2004; 59(1):95-99
137 Bown SG, Rogowska AZ, Whitelaw DE, et al. Photodynamic therapy for cancer of the pancreas. Gut 2002;50(4):549-557

138 DeLaney TF, Sindelar WF, Tochner Z, et al. Phase I study of debulking surgery and photodynamic therapy for disseminated intraperitoneal tumors. Int J Radiat Oncol Biol Phys 1993;25(3): 445-457

139 Khan T, Unternährer M, Buchholz J, et al. Performance of a contact textile-based light diffuser for photodynamic therapy. Photodiagn Photodyn Ther 2006;3(1):51-60

140 Cochrane C, Mordon SR, Lesage JC, Koncar V. New design of textile light diffusers for photodynamic therapy. Mater Sci Eng C Mater Biol Appl 2013;33(3):1170-1175

141 Kim S, Ohulchanskyy TY, Pudavar HE, Pandey RK, Prasad PN. Organically modified silica nanoparticles co-encapsulating photosensitizing drug and aggregation-enhanced two-photon absorbing fluorescent dye aggregates for two-photon photodynamic therapy. J Am Chem Soc 2007;129(9):2669-2675

142 Chatterjee DK, Fong LS, Zhang Y. Nanoparticles in photodynamic therapy: an emerging paradigm. Adv Drug Deliv Rev 2008; 60(15):1627-1637 (Review)

143 Moghissi K, Dixon K. Is bronchoscopic photodynamic therapy a therapeutic option in lung cancer? Eur Respir J 2003;22(3): 535-541

Appendix 1 Photosensitisers, manufacturers, and web sites

\begin{tabular}{|l|l|l|}
\hline Photosensitiser & Manufacturer & Web site \\
\hline Hematoporphyrin derivative & Variable in different countries & $\begin{array}{l}\text { Currently used in laboratories } \\
\text { (see Ref. 11) }\end{array}$ \\
\hline Photofrin & $\begin{array}{l}\text { Pinnacle Biologics, Chicago, } \\
\text { Illinois, United States }\end{array}$ & www.pinnaclebiologics.com \\
\hline Levulan & $\begin{array}{l}\text { DUSA Pharmaceuticals,Wilming- } \\
\text { ton, Massachusetts, United States }\end{array}$ & www.dusapharma.com \\
\hline Metvix & Galderma Pharma SA & www.galderma.com \\
\hline Visudyne & Verteporfin & www.visudyne.com \\
\hline Hexaminolevulinatehydrochloride & Photocure & www.photocure.com \\
\hline Letexaphyrin/lutetium texaphyrin & Pharmacyclics, Inc. & www.pharmacyclics.com \\
\hline Foscan & Biolitec Technology Gmbh & www.biolitec.com \\
\hline Talaporfin & $\begin{array}{l}\text { Light Science Oncology, Bellevue, } \\
\text { Washington,United States }\end{array}$ & info@tacomaradiation.com \\
\hline Photochlor & $\begin{array}{l}\text { AdooQ Bioscience, Irvine, } \\
\text { California, United States }\end{array}$ & info@adooq.com \\
\hline TOOKAD & Steba Biotech & info@stebabiotech.com \\
\hline Photosens & General Physics Institute & www.gpe.ru \\
\hline
\end{tabular}

